\title{
Transition towards sustainable pharmacy? The influence of public debates on policy responses to pharmaceutical contaminants in water
}

\author{
Simon Schaub ${ }^{1 *}$ (1) and Thomas Braunbeck ${ }^{2}$
}

\begin{abstract}
Background: Despite clear-cut scientific evidence for pharmaceutical contaminants causing adverse effects in aquatic life, the regulatory response in Germany has been weak. In principle, there are different policy approaches to address pharmaceutical contaminants: German water protection policies mostly follows a control approach, complemented by end-of-pipe solutions in some German states. The approach leaves the activities of key target groups, such as the pharmaceutical industry, largely unaffected. A stakeholder consultation initiated in 2016 by the German Federal Ministry of the Environment did not lead to significant changes in regulation. Empirical research in political science has shown that analysing the public debate can be helpful in explaining policy responses and, in particular, policy change. This study follows this approach and investigates whether the German policy response to pharmaceutical contaminants can be explained by characteristics of the public debate on the issue.
\end{abstract}

Results: A discourse network analysis based on newspaper reporting in Germany was conducted between 2013 and 2017 to investigate the public debate on pharmaceutical contaminants. German newspapers actually paid considerable attention to the issue. In fact, the debate was not controversial, and participating organisations expressed similar views with regard to the risk of the contaminants, the causes of contamination and the approaches to be taken to mitigate the release of contaminants to the environment. The main narrative in the debate was supportive to the current policy approach applied in Germany. There were no concerted efforts by organisations such as environmental organisations or ecological parties to mobilise for an alternative policy approach.

Conclusions: The low level of polarisation in the policy subsystem and the absence of a strong narrative mobilising a major policy change may explain the persistence of the policy approach to pharmaceutical contaminants applied in Germany. A significant change to the current approach in the near future seems unlikely. Nevertheless, literature in political science shows that a polarised public debate and a strong pro-change actor coalition often preceded policy change. Actors with an interest in stricter regulation might want to reconsider their mobilisation strategies.

Keywords: Pharmaceuticals, Trace contaminants, Aquatic pollution, Discourse network analysis, Policy debate, Water policy, Policy change, Risk governance

\footnotetext{
*Correspondence: simon.schaub@ipw.uni-heidelberg.de

${ }^{1}$ Institute of Political Science, Heidelberg University, Bergheimer Straße

58, 69115 Heidelberg, Germany

Full list of author information is available at the end of the article
}

\begin{abstract}
Introduction
Despite significant improvements in wastewater treatment and water quality protection, the majority of European surface waters (rivers, lakes, transitional and coastal waters) is not in a good ecological condition [114] as required by the European Water Framework Directive
\end{abstract}


[106]. Over the last 20 years, a decrease in fish populations has been documented for numerous river systems in Europe and North America [10, 13, 14], and further ecotoxicological studies revealed that pollution within rivers "is, indeed, significant enough to potentially affect fish populations" [33].

There is growing evidence that pharmaceutical residues in surface waters cause adverse effects in aquatic life [5, 17, 36, 69, 74]. Pharmaceuticals have been designed as biologically active agents to cure diseases and to manipulate biological processes within living organisms. Therefore, it comes with no surprise that such substances are likely to have an effect on non-target organisms in aquatic ecosystems, when present in surface waters even at very low concentrations. Although knowledge on how pharmaceutical residues affect fauna and flora is still limited, several studies indicate adverse effects [16, 18, 22, $59,62]$. Examples of substances with a high potential for ecotoxicological effects commonly detected in aquatic systems include analgesics such as diclofenac [63, 95], hormones such as $17 \alpha$-ethinylestradiol and other steroids [1, 79, 103], antibiotics, antidepressants or antitumor agents (for reviews, see [41] as well as [5]). Pharmaceutical contaminants can meanwhile be detected in almost any environmental matrix all over the world [69]. They partly originate from municipal wastewater, since most currently installed wastewater treatment plants have not been designed to remove such trace contaminants [19, $86,98,102]$. New technologies capable of eliminating these contaminants are still under development, and the number of wastewater treatment plants upgraded to such advanced purification technologies is still small $[51,96]$.

Despite the evidence for adverse effects in aquatic life caused by pharmaceutical contaminants, the regulatory response in Germany has been weak $[25,56]$. In principle, stricter measures could be adopted by policy-makers since the precautionary principle, which is the guiding principle of the European Union for addressing uncertain risks, enables policy-makers to take regulatory action if preliminary evidence suggests that certain activities or substances are harmful to the environment or human health (see e.g. [87]). It remains open why the given scientific evidence in combination with the precautionary principle, which allows stronger regulatory measures, have not lead to a stricter policy response. The present contribution aims to better understand policy formation in this policy field by investigating the research question whether the public debate had an impact on the policy response to pharmaceutical contaminants in Germany. Empirical research in political science has repeatedly shown that the public debate can influence policy-making processes in democratic systems [20, 42, 45, 81, 88, 89]. The public debate represents a space where societal and political issues are publicly debated [70]. For instance, this space can be provided by the media such as newspapers. Within the public debate, political actors interact verbally about a given policy issue [44]. In this study, we argue that the presence of a non-disputed public debate, characterised by a hegemonic actor coalition and the absence of a strong actor coalition mobilising for major policy change, contributed to the persistence of the weak policy response to pharmaceutical contaminants.

In a first step, we present our theoretical argument on the relationship between the public debate and policy responses to pharmaceutical contaminants. The section concludes with two rivalling theoretical expectations. We then explain the data gathering process and the methodology used to investigate the formulated expectations. Subsequently, we present and discuss our empirical results on the relationship between the public debate and the policy response to pharmaceutical contaminants in Germany. Finally, we present concluding remarks and point to avenues for further research.

\section{Theoretical considerations on the impact of the public debate on policy formation}

Different policy responses to pharmaceutical contaminants in water are possible. These differ in the addressed target groups responsible for contamination and in the level of pressure exerted on the addressees. Policy responses can be based on different policy approaches, which vary with regard to the target groups addressed. Source-directed solutions focus on preventing contamination from the onset. They can address consumers, for instance by encouraging them to change to a more sustainable behaviour, the agricultural sector or the pharmaceutical industry directly. One possibility is to target already the production of pharmaceuticals, e.g. by incentivising or encouraging the production of sustainable, environmentally friendlier pharmaceuticals [39]. Research termed "green pharmacy" or "green toxicology" aims at developing novel production processes that follow a life-cycle approach and incorporate environmentally relevant properties, such as biodegradability, already when designing a new substance $[15,38,40]$. For instance, Rastogi et al. [71] illustrate that it is also possible to redesign many existing pharmaceuticals and improve their environmental biodegradability through small molecular modifications. Moreover, new predictive toxicology methods that apply in silico approaches could be used to predict the ecotoxicology of pharmaceuticals already when designing new substances [32]. Endof-pipe solutions aim at removing contaminants from water, mainly by improving wastewater treatment. These solutions mostly target the wastewater treatment sector. However, the costs for upgrading wastewater treatment 
can also be passed to the other target groups. Control approaches represent preliminary strategies to monitor the level of contamination. Based on the monitoring, policy-makers may take further policy actions if deemed necessary [57].

In order to implement these approaches, different types of policy instruments can be used, which differ in the level of pressure exerted on the target groups. Relevant policy instruments can be categorised as voluntary, command-end-control, and market-based instruments [57, 93]. Voluntary instruments aim at changing behaviour without exercising coercion, for example by raising problem awareness among consumers or by negotiating voluntary agreements with the industrial sector [101]. These instruments typically exert only soft pressure on target groups, as non-compliance does not entail any direct consequences. Command-and-control instruments directly regulate or impose a desired behaviour, for example by increasing the strictness of authorisation procedures or by banning certain substances [48]. Here, the pressure on target groups is strong, since these are forced to comply with the rules. Market-based-instruments aim at encouraging a desired behaviour through "positive" or "negative" financial incentives [66, 75]. Subsidies for the development of more environmentally friendly production processes are an example for a positive incentive, whereas imposing taxes on less environmentally friendly products represents a negative incentive. The level of pressure on target groups can be regarded as intermediate, since these are not forced to comply with rules, but face certain economic disadvantages [57].

We argue that a change in the overall policy approach, i.e. from a control to a source-directed approach, or a significant change in the pressure put on target groups, i.e. from 'soft' voluntary measures to 'hard' commandand-control regulation, can be classified as a major policy change in this policy subsystem.

\section{Coalition formation based on policy beliefs}

In order to analyse the impact of the public debate on policy formation, we draw on theories of policy process. Empirical research in political science has shown that analysing the public debate can be helpful for explaining policy change [42, 44]. Policy-making takes place in a complex and intertwined setting that includes a variety of public and private actors with an interest in shaping public policy [37]. Policy process theories, most prominently the 'Advocacy Coalitions Framework' [78], suggest that these political actors express their policy beliefs in policy debates and form 'actor coalitions' based on competing policy beliefs. Thus, actors' policy beliefs structure coalitions in a policy subsystem. Actors with similar policy beliefs form coalitions and diverge from other coalitions of actors with opposing policy beliefs [42, 76, 97, 100]. Coalition formation can, therefore, be measured empirically based on the policy beliefs actors articulate in the public debate in the media or other arenas [42].

\section{Why do political actors reveal their policy beliefs in the public debate?}

The different policy approaches and instruments discussed before address the behaviour of different actors. Most prominently, these include actors from the industrial sector, the agricultural sector, the water treatment sector, or consumers and consumer protection organisations as their representatives. Depending on the choice of policy instruments and their respective addressees, these actors are confronted with additional costs. Therefore, the different actors should have an interest in influencing the policy-making process proactively either to promote their preferred solutions or to prevent undesired policy instruments from being adopted. In addition, there are actors with an intrinsic interest in protecting the environment, such as environmental groups or ecological political parties that may evaluate certain policy approaches to be more effective than others.

Political actors use the public debate as a venue to influence policy-making [42, 44]. In fact, these actors participate in the public debate and articulate their policy beliefs for strategic reasons [81, 89]. There are various arguments in literature on how participation in the public debate can be influential on policy formation: First, new information can lead to policy learning, which has been identified as a driving force for policy change [42, 46, 77]. Thus, political actors participate in the debate in order to put forth their arguments or new information in order to trigger policy learning across coalitions. Second, through emphasising certain policy issues and solutions, but neglecting others, the public debate may have a profound impact on agenda-setting, making some policy issues and solutions more likely to be discussed in parliament than others $[4,83,90,92]$. Third, the public debate can shape public opinion [73], which may then affect politicians in their decision-making [84]. In democratic systems, political actors are inclined to respond to public demands in order to secure an electoral benefit $[8,82,83]$.

\section{Which coalition structures make policy change more likely?}

Depending on the participation of political actors and their articulated policy beliefs, different coalition formation structures arise. One can differentiate between three ideal types of coalition formation structures: (1) adversarial or polarised structures with opposing coalitions and little coordination, (2) collaborative structures with opposing but coordinated coalitions, and (3) unitary or 


\section{Adversarial}
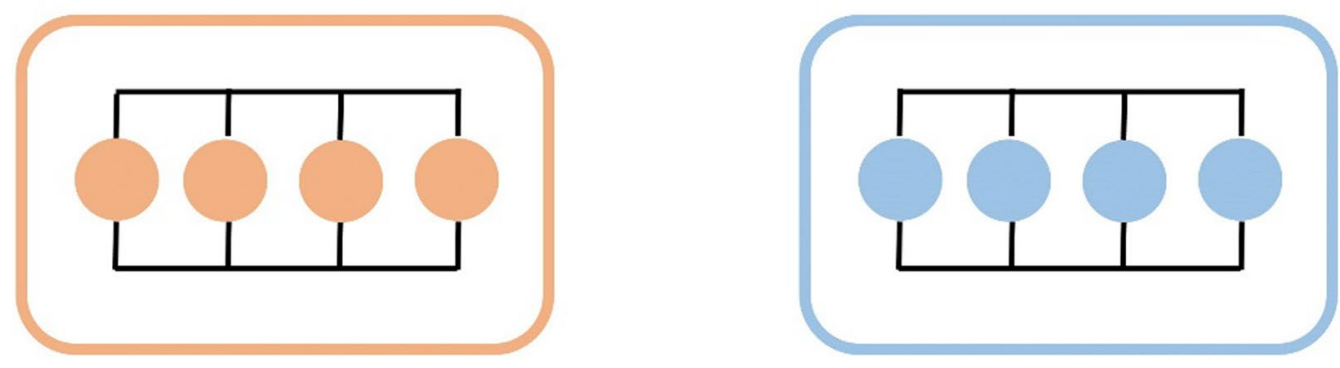

Collaborative

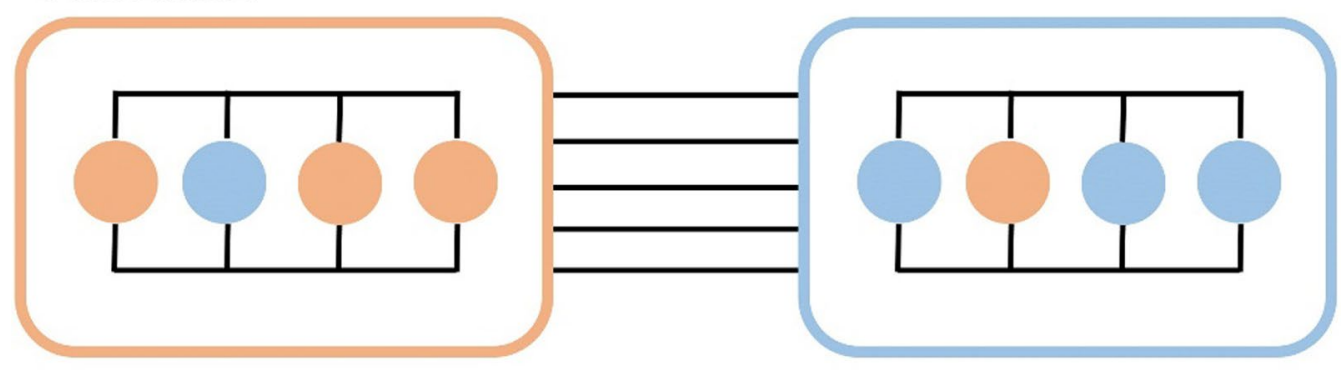

Unitary

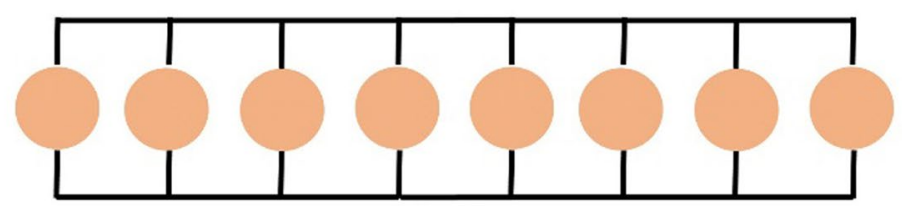

Fig. 1 Three coalition structures. Based on Metz [56]

hegemonic structures that consist of one dominant coalition [30]. See Fig. 1 for an illustration of the different coalition structures. Adversarial structures are typical for conflictual subsystems, whereas a unitary structure is indicative for the absence of conflict in policy formation [42].

Unitary coalition structures are usually stable over time $[3,4]$. In a subsystem characterised by a unitary coalition structure, the hegemonic coalition has determined policy formation and, therefore, the current policy status quo. The structure will remain stable unless political actors outside the hegemonic coalition challenge the status quo and start to mobilise for a policy change [28]. This challenge would lead to a polarised coalition structure, which in turn could result in policy learning, a change in agenda-setting of parliaments, and increase pressure on decision-makers to respond to potential unfavourable public opinion. Thus, major policy change should be preceded by a polarisation of the coalition structure. Complementary, the persistence of a unitary coalition structure should make a change to the policy status quo less likely [42].

These theoretical considerations lead to the following two competing expectations, which we will investigate in the remainder of this study:

Expectation 1a: The presence of a disputed public debate that is characterised by an adversarial or collaborative network structure and an actor coalition that advocates a change in the policy status quo increases the likelihood for a major policy change.

Expectation 1b: The presence of a non-disputed public debate that is characterised by a unitary network structure and a hegemonic coalition that supports the policy status quo decreases the likelihood for a major policy change. 


\section{Methods applied in the present study}

We applied a discourse network analysis [43-45] to test the plausibility of our theoretical expectations formulated in the previous section. Due to the small-N research design, we conduct a plausibility probe, which may then guide future theory development [49]. Discourse network analysis has repeatedly and successfully been applied in the study of policy formation and policy change [20, 42, $43,67,72,80,89]$. The process of policy-making is inherently a relational phenomenon where actors depend on each other to make collective decisions. Discourse network analysis can be used to investigate interdependencies between the actors that participate in policy-making. The approach combines qualitative content analysis with social network analysis and allows to analyse these interdependencies based on the policy beliefs actors articulate in policy debates [42]. Actors' policy beliefs are measured via statements they formulate in the public debate. These statements are text portions where actors indicate support of or opposition to a concept [42]. Therefore, actors' positions towards certain concepts, such as their stance on a policy approach or a policy instrument, represent an operationalisation of their policy beliefs. In this study, we defined actors as organisations that participated in the policy debate on pharmaceutical contaminants such as environmental organisations, political parties, government agencies, or companies. Network analysis then allows to analyse coalition formation based on these organisations' shared policy beliefs [42].

We selected newspaper articles as data source for our analysis, because our research interest focused on the public debate. For clarity, we underline that these newspaper articles served as a data source to measure actors' publicly articulated policy beliefs. We are not interested in how the media might present or frame the issue of pharmaceutical contaminants. Following Leifeld [42], we used the Frankfurter Allgemeine Zeitung (FAZ), which is one of the principal nation-wide newspapers in Germany, as primary data source. ${ }^{1}$ We further included articles from at least one principal regional newspaper from each of the German States (leading to 23 sources in total) in order to secure a sufficiently fine-meshed coverage (Additional file 1: Table S1 and Figure S1). We identified relevant articles by using a keyword search within the respective newspapers. ${ }^{2}$ This search strategy resulted in 826 newspaper articles that dealt with pharmaceutical contaminants in surface waters published between January 2013 and December 2017. Within these articles, we

\footnotetext{
1 The FAZ corresponds well with the "quality press" criterion of wide circulation and being politically moderate and reputable [2].

2 A full list of these combinations is provided in the supplemental materials.
}

coded 666 statements where organisations expressed relevant policy beliefs by using the software Discourse Network Analyzer [47]. All articles were encoded manually by one of the authors and two research assistants.

In order to measure actors' policy beliefs, we coded their stance on four different types of policy aspects relevant for this policy subsystem (see Fig. 2 for an overview). First, we coded actors' risk perception in order to capture whether they framed the issue of pharmaceutical contaminants in certain ways in order to increase or diminish attention to the topic. This included whether actors agree or disagree that pharmaceutical contaminants represent a risk to the environment or to human health or whether the risk is unknown. Second, we captured how responsibility for the entry of contaminants is attributed. More specifically, we coded whether actors assign responsibility either to the pharmaceutical industry, the agricultural sector, the consumers, or to the wastewater treatment sector. Third, we coded actors' positions towards possible policy approaches. Actors referred to three different target groups when mentioning source-directed approaches: the pharmaceutical industry, the agricultural sector and consumers. In addition, actors referred to the wastewater treatment sector when discussing an end-of-pipe approach. Fourth, we coded actors' preferences towards specific policy instruments. These included different regulatory measures, such as product bans or environmental quality standards, and market-based instruments, such as subsidies or taxes. We derived these four categories deductively based on our theoretical considerations and background knowledge on this policy issue. The codebook was then modified stepwise based on a first round of coding. Modifications mostly corresponded to specific policy instruments, which we then added to the codebook. Differences in policy beliefs as measured by agreement or disagreement with these policy aspects should, in principle, enable us to differentiate between actors who support a current policy status quo from those who mobilise for a policy change.

We then applied different methods to analyse the data: In a first step, we computed descriptive statistics to gain a first insight in what type of actors took part in the public debate and which policy beliefs predominated. For this purpose, we compared the actors' share of statements and the share of policy beliefs.

In a second step, we derived a one-mode actor subtract network, where we linked organisations depending on whether they shared positions on the four different types of policy aspects. The subtract network combined congruence and conflict networks, which means that they included both agreement and disagreement on policy aspects. In congruence networks, organisations are linked with an edge if they both share the same policy 

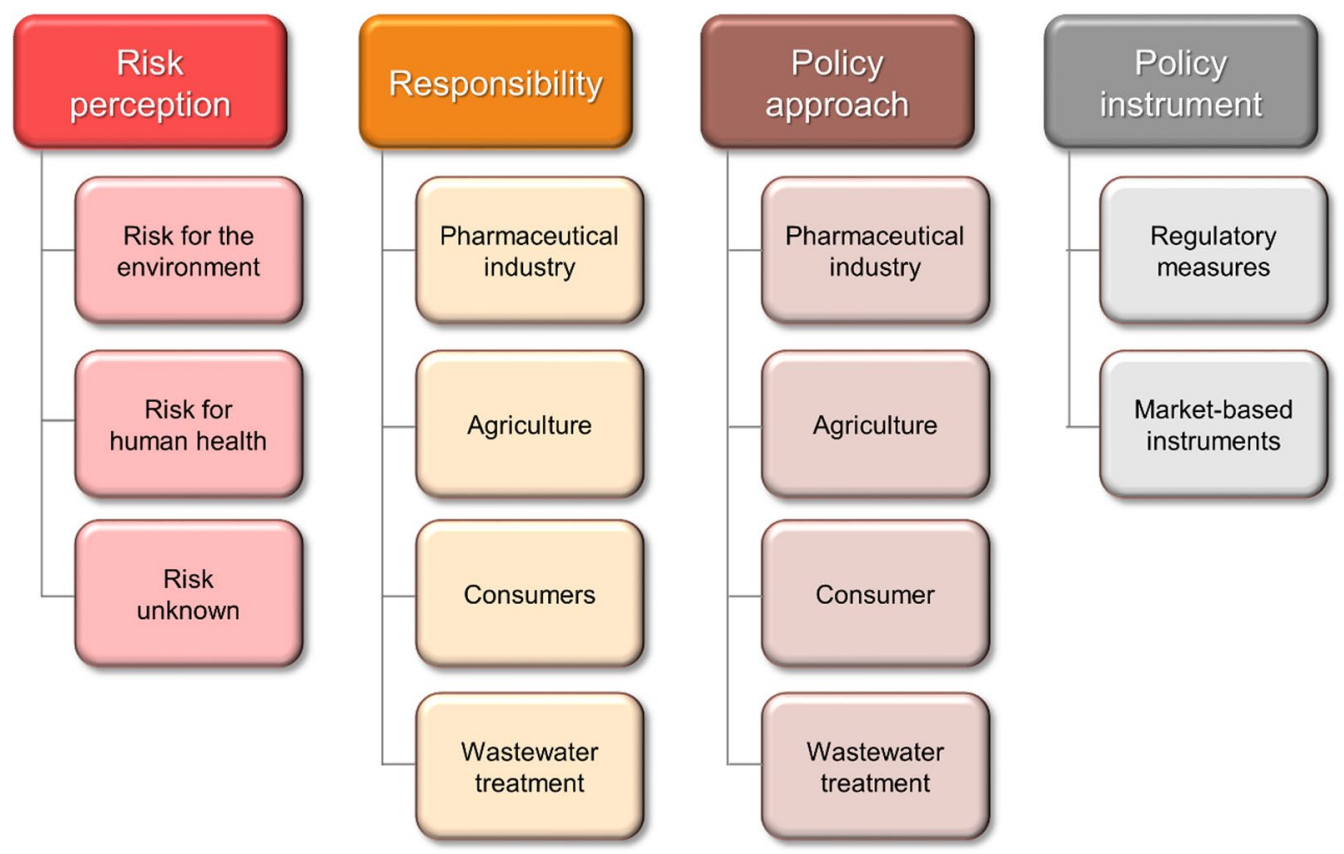

Fig. 2 Measurement of policy beliefs via four different types of policy aspects

belief, i.e. mutual agreement or disagreement with a policy aspect. The more beliefs two actors share, the higher their edge weight. In conflict networks, organisations are linked with an edge if two organisations have conflicting positions on the same policy aspect. The more policy beliefs two actors do not share, the higher their edge weight in the conflict network. The subtract network combines both approaches by subtracting conflict network edge weights from congruence network edge weights. We further normalised the subtract network by applying the Jaccard similarity measure, which is known for its normalising function. The measure divides each edge weight by the sum of the two respective actors' independent and joint referrals to the policy aspects $[47,50]$. One-mode actor networks should be normalised, if the goal is to identify coalition structures, which otherwise could be masked because of different activity levels in the debate $[44,47]$. The resulting matrix contained organisations in rows and columns, with cell values indicating the degree of shared policy beliefs and ranging from -1 to 1 . High values indicated high belief similarity and low values low belief similarity. We then graphically portrayed this actor subtract network by placing organisations as nodes in a two-dimensional space using the Fruchterman-Reingold force-directed placement algorithm The algorithm is commonly applied in social network analysis and groups nodes, which share more connections to each other, closer together. At the same time it reduces overlap of nodes and, thereby, improves readability of a graph $[21,65]$. In the graph, nodes were only linked by edges, if they shared cell values greater than zero indicating a certain degree of belief similarity (see Nagel [61] for a similar application). This graphical approach allows to evaluate the structure of networks and to identify actor clusters, since actors with higher degrees of similarity are placed closer to each other [47]. In addition, we conducted a community detection analysis with the help of the Louvain algorithm to complement the graphical analysis of coalition structures. The method identifies communities within networks based on a modularity measure and a hierarchical approach [9]. Modularity measures the strength of community structures compared to a random network with identical sets of nodes and edges [52]. Communities are more similar subsets of nodes and may, therefore, represent actor coalitions as their similarity is determined based on their shared policy beliefs. In order to better understand the division between communities and to evaluate whether these can be interpreted as opposing coalitions, we added a qualitative analysis of their shared beliefs.

Finally, we complemented our analysis of actor coalition structures with an analysis of structures in the policy narrative. For this purpose, we derived a one-mode concept congruence network. In these networks, concepts represent the nodes which are linked by edges if they are co-referenced by an identical actor. Here, we linked any two policy aspects if they were co-referenced by the same organisation. More specifically, we subdivided the policy 
aspects into agreement and disagreement (e.g. agreement with a risk for the environment and disagreement with a risk for the environment). The resulting matrix contained the subdivided policy beliefs in rows and columns, with cell values indicating the number of actors that articulated the same two policy beliefs (e.g. 22 of the organisations that stressed the responsibility of consumers also supported a policy approach that focuses on upgrading wastewater treatment). We also illustrated the concept congruence network by placing the subdivided policy beliefs as nodes in a two-dimensional space using the Fruchterman-Reingold force-directed placement algorithm. This approach enables an analysis of the structure of policy narratives. If two or more clusters of policy beliefs form in the network, then these can be interpreted as competing storylines in the policy debate [43, 44].

\section{Results}

In this section, we first evaluate the policy response to pharmaceutical contaminants in Germany and analyse whether a major policy change occurred over time. Subsequently, we analyse the public debate in Germany and evaluate its impact on policy formation.

\section{Policy response to pharmaceutical contaminants}

Since Germany is a member state of the European Union (EU), EU legislation needs to be translated into domestic legislation. Thus, legislation at the federal and the statelevel is dependent on regulatory activity at the EU-level. This also applies to water legislation $[25,56]$.

The EU Water Framework Directive [106] is one of the EU's central water policies and relevant for the regulation of pharmaceutical contaminants. Its main goal is to achieve a good ecological condition of European water bodies. Among others, the directive aims at reducing the entry of priority hazardous substances into water. These substances are defined to have toxic, persistent or bio-accumulative properties or cause equivalent levels of concern to have adverse effects on human health or aquatic ecosystems [106]. EU member states are obliged to monitor these substances and to adopt measures to mitigate their entry into water. Measures should be based on the precautionary principle, primarily address the source of contamination, and follow the polluter-pays principle [106]. The priority hazardous substances are defined by a priority substances list that is meant to be updated regularly [109]. The list entails 45 priority substances since the last revision in 2013. In addition, the EU assigned an Environmental Quality Standard (EQS) to every priority substance on this list. These define concentration limits for the specific substance. In case a limit is exceeded, policy-makers are required to take measures in order to reduce the entry of the respective pollutant
$[25,56]$. Until today, the list did not include any pharmaceutical substances $[106,108,109]$. However, the EU also laid down a watch list of substances that includes potentially hazardous substances for aquatic ecosystems [104, 105]. These substances are required to be monitored only by EU member states and will be added to the priority substances list upon decision by the European Commission Joint Research Centre if their occurrence in water bodies across Europe has been proven [26, 27]. Several pharmaceutical substances have been added to the list including sexual hormones (17-alpha-ethinylestradiol, 17-beta-estradiol estrone, and estrone), one painkiller (diclofenac), and various antibiotics (macrolide antibiotics, amoxicillin, and ciprofloxacin). Diclofenac has been removed from the watch list in the latest update in 2018, because its European-wide occurrence in environmentally relevant concentrations could not be proven [105]. Nevertheless, Hillenbrand et al. [26] emphasise that there are analytical difficulties to detect residues in water and point towards the high amounts of production and consumption of the substances on this list that actually point towards considerable emissions of these substances into water. Finally, the Water Framework Directive required member states to select river basin-specific substances and define EQSs. The EU did not specify the specific substances but left the decision to include the substances to member states[56, 106].

Altogether, EU legislation required Germany to adopt new water legislation that addresses the entry of hazardous substances into water $[25,56]$. As laid down by the watch list of substances, potential hazardous substances also included pharmaceutical contaminants. These were only required to be monitored. However, the river basinspecific substance list gave Germany the opportunity to also take mitigating measures that address pharmaceutical contaminants present in German waters at environmentally relevant concentrations, such as Diclofenac [53, 85]. Finally, the directive was clear in its recommendation to primarily adopt a source-directed approach and put pressure on polluters via the polluter-pays principle [25].

\section{Water policies at the federal level}

The German Surface Water Ordinance [111], adopted in 2011, and the Federal Water Act [113], adopted in 2009, are the two main water legislations at the federal level in Germany. Both transpose the EU Water Framework Directive into domestic law [7, 25]. The OGewV is of main importance for this study because it regulates the entry of hazardous substances in water bodies in Germany. It has been designed in accordance with a control approach [56]. As requested by the Water Framework Directive, the ordinance specifies EQSs for a list of river basin-specific substances. The OGewV has two 
significant limitations with regard to the regulation of pharmaceutical contaminants. First and foremost, the list of 67 substances does still not include a single pharmaceutical contaminant [111]. When the ordinance was drafted, opposition by the German states prevented the listing of some new river basin-specific substances, including pharmaceutical chemicals [56]. Second, the OGewV only states that further political measures need to be taken to mitigate immissions in case an EQS is exceeded. It does not specify what measures were to be taken and what sanctions polluters would face [56]. The approach mainly builds on point pollution where specific polluters can be identified on a case-by-case basis and then be held responsible. However, the entry of pharmaceuticals into water bodies is more complex and the identification of polluters is not unambiguous [5]. Thus, the behaviour of relevant target groups (like the pharmaceutical industry as an indirect polluter) would be difficult to address even if pharmaceuticals were added to the list in the future [56].

Source-directed approaches to address pharmaceutical residues in water are largely absent in Germany. Such an approach could target the producers of pharmaceuticals, for instance [27]. However, the authorisation of human medicines in Germany does not necessarily depend on a prior environmental risk assessment [64]. The authorisation procedure in Germany is regulated at the EU level under EU Directive 2001/83/EC [107] and Regulation (EC) No 726/2004 [112] and on the national level under the German Medicinal Products Act [110]. Although the authorisation of new pharmaceuticals requires an environmental risk assessment, the assessment is not decisive for an authorisation decision and, in addition, has only been mandatory for newly marketed drugs since 2005. In fact, most frequently consumed pharmaceuticals were authorised before 2005 [5]. Therefore, there is no significant incentive for the pharmaceutical industry to produce more environmentally friendly pharmaceuticals. With regard to end-of-pipe solutions, there is no legal requirement for wastewater treatment plants to upgrade their wastewater technology in order to be able to filter pharmaceutical contaminants. Improving the treatment technology has remained a voluntary decision by the operators [56].

In 2016, the German Federal Ministry of the Environment initiated a stakeholder consultation to develop a new federal strategy on micropollutants in water, including pharmaceutical contaminants. Invited stakeholders included industry representatives, agricultural associations, environmental groups, consumer protection organisations, representatives of the water treatment sector, scientists and representatives of the German states. The initiative had the potential to induce a change regarding the regulation of pharmaceutical contaminants. However, the results of the stakeholder consultation represented in March 2019 do not suggest that a major change in the approach is likely in the near future [115]. Participating stakeholders were only successful in agreeing on voluntary policy measures such as a new round table and an information campaign that addresses consumers' consumption behaviour. Therefore, relevant regulation for pharmaceutical contaminants in Germany at the federal level still mostly follows a control approach with a strong emphasis on 'soft' voluntary measures.

\section{Implementation at the state-level}

The German states are responsible for the implementation of the rules set out by the OGewV and need to comply with the defined concentration limits at the federal level $[25,56]$. Since the OGewV does not determine political measures in case EQSs are exceeded, the German states enjoy some freedom in their regulatory response. With the exception that the states are not allowed to develop own regulations that address the emission of substances [7, 25]. As there are no concentration limits defined for pharmaceutical contaminants at the federal level, the German states de jure do not need to take regulatory measures, except for monitoring [111]. Nevertheless, some German states have developed their own strategies on how to address the entry of pharmaceutical contaminants and implemented policy measures. These measures mostly follow an end-of-pipe approach, which aims at upgrading wastewater treatment technology at selected treatment plants, and a source-directed approach that aims at changing the behaviour of consumers through information campaigns. States that pursue an end-of-pipe approach include Baden-Württemberg [121, 122], Hessen [116], North Rhine-Westphalia [117], and to some degree Bavaria [120] and Saarland [119]. The former have provided financial support for operators who voluntarily upgrade their treatment technology, whereas the latter only have funded pilot studies or scientific research in the development of new treatment technologies. Information campaigns have been part of the strategies of Hessen [116], and North Rhine-Westphalia [118]. The remaining states have not taken any measures. Some of them explicitly state that they wait for further regulatory action at the EU-level before taking any measures $[25,56]$.

\section{Major policy change?}

Theoretically, we argued that a major policy change in the regulation of pharmaceutical contaminants would involve a significant change in the overall approach or in the pressure policy instruments put on target groups. As detailed above, Germany has adopted a control approach 
Table 1 Frequency of organisations and statements per type of organisation in the public debate

\begin{tabular}{|c|c|c|c|}
\hline Type of organisation & Organisations & Statements & $\begin{array}{l}\text { Share } \\
\text { of statements } \\
(\%)\end{array}$ \\
\hline Agricultural association & 3 & 4 & 0.6 \\
\hline Fishery association & 1 & 1 & 0.2 \\
\hline Pharmacy association & 7 & 14 & 2.1 \\
\hline Medicine association & 3 & 3 & 0.5 \\
\hline Industry, retail & 2 & 6 & 0.9 \\
\hline Water association, municipal utility & 68 & 201 & 30.2 \\
\hline Water company & 11 & 28 & 4.2 \\
\hline Environmental organisation & 6 & 45 & 6.7 \\
\hline Consumer protection organisation & 4 & 13 & 1.9 \\
\hline Green party & 14 & 72 & 10.8 \\
\hline Leftist party & 1 & 1 & 0.2 \\
\hline Social Democratic Party & 4 & 9 & 1.4 \\
\hline Christian Democratic Party & 6 & 7 & 1.1 \\
\hline Liberal party & 3 & 3 & 0.4 \\
\hline Federal government & 5 & 63 & 9.5 \\
\hline State government & 18 & 64 & 9.6 \\
\hline Regional, local government & 14 & 22 & 3.3 \\
\hline Science & 30 & 110 & 16.5 \\
\hline Sum & 200 & 666 & 100.0 \\
\hline
\end{tabular}

at the federal level that has been complemented by endof-pipe solutions by only a few selected German states. Over the course of time, there has not been a significant change to this overall approach. The pressure on target groups has been low. Command-and-control regulation that would force operators to update their treatment technologies have not been adopted. The same applies for market-based instruments that would push producers to develop more environmentally friendly pharmaceuticals or consumers to consume pharmaceuticals more environmentally consciously. Therefore, the emitters of pharmaceutical contaminants are not directly targeted and there is no pressure to change behaviour. The only measures taken were voluntary and can be expected to exert only 'soft' pressure on relevant target groups (see Metz [56] for a detailed evaluation). A significant change in the measures adopted could not be observed. To conclude, the policy status quo in Germany has been predominantly a control approach in combination with 'soft' policy measures. A major policy change did not occur.

\section{Public debate and its impact on the policy response}

In the subsequent section, we first provide some descriptive statistics on actor participation and the policy beliefs expressed in the public debate. We then turn to the main part where we analyse the coalition structure. In addition, we shed some light on the structure of policy narratives in the public debate. We conclude by relating our empirical findings to our theoretical expectations with regard to an impact of the public debate on policy formation.

\section{Participation of political actors}

Overall, persons affiliated with 200 different organisations issued 666 statements on pharmaceutical contaminants in the selected newspaper articles between January 2013 and December 2017. Table 1 presents descriptive statistics for different types of organisations, including the number of organisations per type and the frequency of statements.

The public debate was dominated by political-administrative actors, science, and organisations affiliated with the sectors of wastewater treatment and water provision (together $73.3 \%$ of statements). Political-administrative actors from different regulatory levels contributed the second highest share of statements. Among these, actors representing the federal and state levels were most active (9.5 and 9.6\%, respectively), which coincides with the fact, that responsibilities for water protection lie mostly on the federal and the state levels. The German Federal Environmental Protection Agency (UBA) was the most active single organisation with 52 statements (7.8\%). Universities and other higher education institution accounted for $16.5 \%$ of the statements. The largest share of statements stemmed from wastewater treatment and 
Table 2 Frequency of expressed policy beliefs in the public debate

\begin{tabular}{|c|c|c|c|c|c|c|c|}
\hline \multirow[t]{2}{*}{ Policy beliefs } & \multicolumn{2}{|c|}{ Agreement } & \multicolumn{2}{|c|}{ Disagreement } & \multicolumn{3}{|c|}{ Total } \\
\hline & $\Sigma$ & $\%$ & $\Sigma$ & $\%$ & $\Sigma$ & $\%$ & \\
\hline Risk for the environment & 87 & 13.1 & 0 & & 87 & 13.1 & \\
\hline Risk for human health & 24 & 3.6 & 43 & 6.5 & 67 & 10.1 & \\
\hline Risk unknown & 32 & 4.8 & 0 & & 32 & 4.8 & \\
\hline Consumers responsible & 115 & 17.3 & 0 & & 115 & 17.3 & \\
\hline Agriculture responsible & 38 & 5.7 & 1 & 0.2 & 39 & 5.9 & \\
\hline Pharmaceutical industry responsible & 13 & 2.0 & 0 & & 13 & 2.0 & \\
\hline Wastewater treatment responsible & 74 & 11.1 & 0 & & 74 & 11.1 & \\
\hline Policy approach: consumer & 54 & 8.1 & 0 & & 54 & 8.1 & \\
\hline Policy approach: agriculture & 19 & 2.9 & 1 & 0.2 & 20 & 3.0 & \\
\hline Policy approach: pharmaceutical industry & 42 & 6.3 & 0 & & 42 & 6.3 & \\
\hline Policy approach: wastewater treatment & 72 & 10.8 & 16 & 2.4 & 88 & 13.2 & \\
\hline Policy instrument: tax & 3 & 0.5 & 1 & 0.2 & 4 & 0.6 & \\
\hline Policy instrument: subsidy & 1 & 0.2 & 0 & & 1 & 0.2 & \\
\hline Policy instrument: authorisation & 14 & 2.1 & 1 & 0.2 & 15 & 2.3 & \\
\hline Policy instrument: application & 4 & 0.6 & 0 & & 4 & 0.6 & \\
\hline Policy instrument: product ban & 1 & 0.2 & 0 & & 1 & 0.2 & \\
\hline Policy instrument: EQS & 10 & 1.5 & 0 & & 10 & 1.5 & \\
\hline Sum & 603 & 90.5 & 63 & 9.5 & 666 & & 100.0 \\
\hline
\end{tabular}

water provision (30.2 and 4.2\%). These included water associations such as the BDEW (Federal Association of the Energy and Water Industry) and the DWA (German Association for Water Management, Wastewater and Waste), smaller municipal utilities or private water companies. Not only their share of statements, but also their number was largest compared to the other types of organisations. We identified 72 statements by the German Green party (10.8\%), 45 statements by environment organisations $(6.7 \%)$ and 13 statements by consumer protection organisations (1.9\%). Only two organisations affiliated with industry or retail appeared in the public debate: the German Pharmaceutical Industry Association $(\mathrm{BPI})^{3}$ and the Association of Research-Based Pharmaceutical Companies (VFA). In total, these organisations made six statements equivalent to $0.9 \%$ of the sum of statements. The presence of organisations affiliated with agriculture was even lower $(0.6 \%)$.

\section{Policy positions taken in the debate and degree of dispute}

We further give some insights into the policy beliefs actors expressed in the debate. Table 2 shows how frequent actors referred to the different policy aspects, either with a supportive or opposing stance. The table

\footnotetext{
${ }^{3}$ For a full list of organisations and their abbreviations, please refer to Additional file 1: Table S2.
}

reports absolute numbers of statements as well as percentages on the total number of statements. Overall, the policy beliefs expressed in the debate indicate a low level of conflict. Most statements indicated a supportive stance towards the various policy aspects (90.5\%). Only a small number of statements revealed opposition towards discussed sources of pollution, policy approaches, or policy instruments (9.5\%).

The majority of statements on policy approaches advocated for addressing consumer behaviour (8.1\%) or upgrading wastewater treatment (10.8\%). Opposition towards these approaches was low. However, the endof-pipe approach faced some opposition (2.4\%)-mainly by actors representing municipal utilities or water associations such as the BDEW (Federal Association of the Energy and Water Industry). Within these statements, organisations mostly did not per se argue against upgrading wastewater treatment, but against prioritising the end-of-pipe approach while neglecting source-directed approaches. The share of statements that advocate source-directed approaches in the pharmaceutical industry or agriculture was comparatively smaller (6.3 and $2.9 \%$, respectively).

The pattern was similar with regard to identifying the sources of pollution and attributing responsibility. Most statements saw the responsibility with consumers and wastewater treatment (17.3 and $11.1 \%$, respectively). Organisations held responsible (1) the consumers 


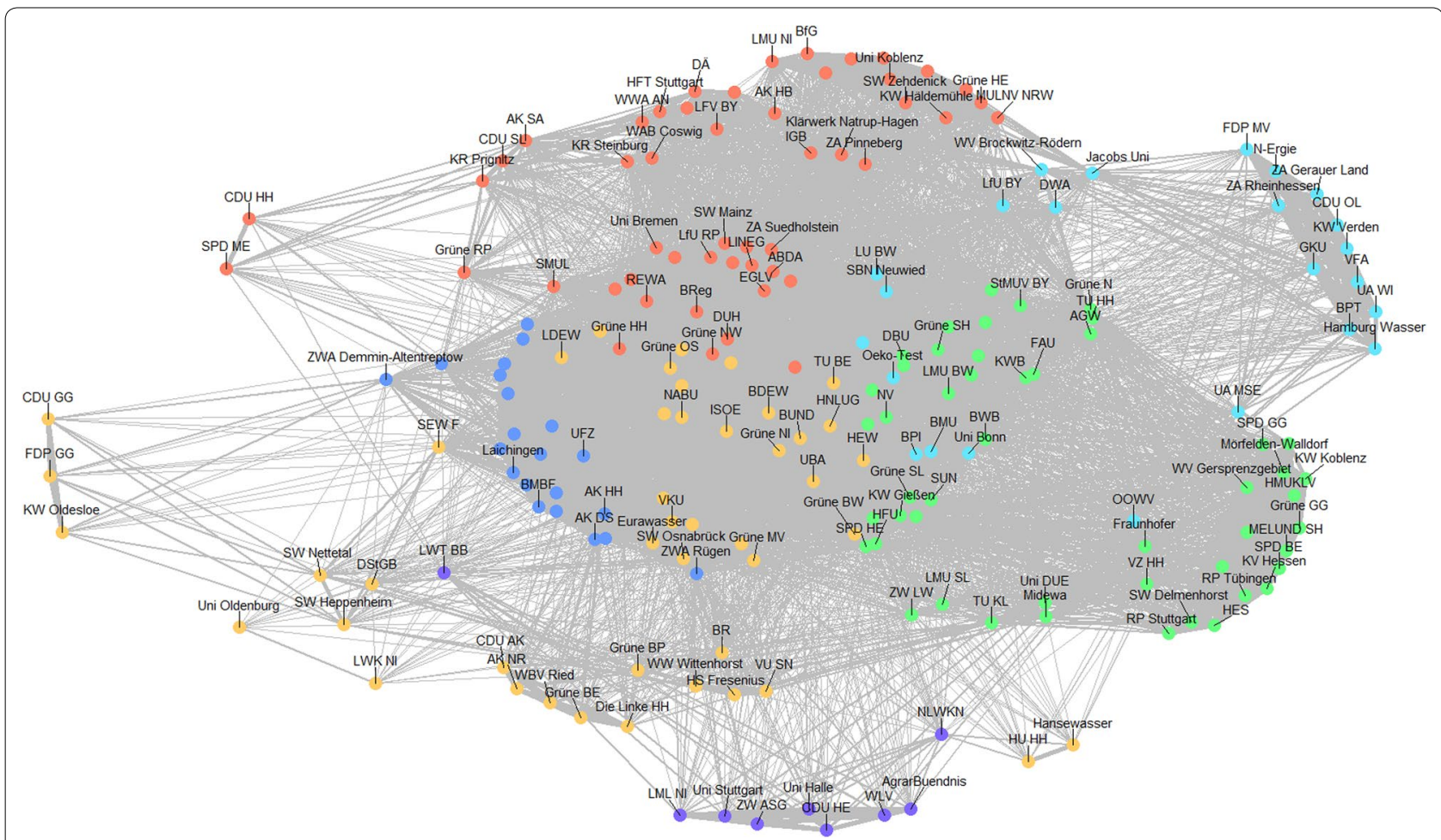

Fig. 3 Normalised actor subtract network based on actors' policy beliefs. Line widths are dependent on belief similarity between organisations. For explanation of abbreviations, please refer to Additional file 1: Table S2

for pollution mainly because of inappropriate disposal behaviour and (2) the wastewater treatment sector for not being able to eliminate contaminants from the sewage water. Responsibility was comparatively less often attributed to the pharmaceutical industry or the agricultural sector (2.0 and $5.7 \%$, respectively).

Statements on particular policy instruments were rare and issued only by a few organisations. EQSs characterise the current water policy in Germany to a large degree, and some organisations advocated for applying new limits for pharmaceutical residues (1.5\% of statements). A slightly larger share of statements showed approval for restricting the authorisation of pharmaceuticals (2.1\%), with only one opposing statement by the BPI (0.2\%). Restricting the application of certain pharmaceuticals, another command-and-control measure, was hardly debated (0.6\%). Market-based instruments, including taxes and subsidies, were mentioned only five times $(0.9 \%)$. Overall, the public debate did not pay much attention to tangible policy instruments.

Finally, there was general agreement that pharmaceutical residues pose a risk for the environment (13.1\%) or that the risk remains unknown (4.8\%). The main exception from this pattern was actors' position on a possible risk for human health. The majority of statements explained that pharmaceutical residues do not pose a risk to human health (6.5\% compared to $3.6 \%)$. These statements were mostly related to discussions on drinking water quality, which, in fact, can be rated as very good to excellent due to Germany's very high standards for drinking water protection [94].

\section{Actor coalitions in the policy debate}

The analysis of coalition structures revealed a unitary network structure without conflicting actor coalitions. Figure 3 visualises the actor subtract network with nodes representing organisations and edges their degree of similarity with regard to their policy beliefs. The node colours indicate the organisations' membership to six different communities as determined by the Louvain algorithm.

A first visual inspection of the network graph with regard to the location of nodes and edges reveals a unitary coalition structure. Most actors cluster in the middle of the graph and share many policy beliefs as indicated by the high density of edges linking the nodes. There are only a few smaller groups on the outside which are characterised by higher belief similarity compared to other actors in the network. The visual interpretation does clearly indicate the absence of an adversarial coalition structure. If present, the graph would show two clearly separated clusters characterised by many edges within 
coalitions and no, or at least only a few, edges between coalitions.

Community detection with the help of the Louvain algorithm suggests that, in fact, six different actor groups were present in the network. These consisted of three large groups with 50, 49 and 45 actors, two mediumsized groups with 24 and 21 actors, and one small group consisting of 9 actors. Subsequently, we analysed these groups and their shared policy beliefs in detail in order to investigate whether they represent adversarial actor coalitions. Additional file 1: Annex $C$ contains visual overviews of actors' policy beliefs for each group separately.

The largest group is coloured in red in Fig. 3. Many actors in this group shared the beliefs that wastewater treatment and consumers were responsible for contamination by pharmaceuticals and that these represented a risk to the environment. However, these actors mostly did not articulate their preferred policy approach or policy instruments to regulate the issue. The second largest group is coloured in green in Fig. 3 and can be termed as the "end-of-pipe-coalition". Actors in this group all shared the belief that policy measures should address wastewater treatment. Some also favoured solutions that address consumption behaviour. Although these actors seemed to be united in how they preferred pharmaceutical contaminants to be addressed, they did not take a clear position on what type of policy measures should be implemented. The group of actors coloured in orange in Fig. 3 is more difficult to classify since actors in this group shared many positions but also had divergent policy beliefs. Apparently, some of the actors in this group explicitly rejected the end-of-pipe approach. Most of these actors were water associations. Furthermore, actors in this group mostly pointed towards the responsibility of consumers and suggested to follow a source-directed approach that addresses consumption behaviour. This group could have represented a counterpart to the "end-of-pipe-coalition" described before. The group of actors coloured in dark blue in Fig. 3 appears to be similar to the one coloured in orange. Actors in this group all shared the belief that consumers were responsible for contamination. The group consisted mostly of water associations, municipal communities or water companies, and science. However, this group also did not indicate clearly their preferred policy approach or policy instruments. The group of actors coloured in light blue in Fig. 3 was characterised by their shared belief that pharmaceutical contaminants do not represent a threat to human health. Some of these shared the belief that there is a risk for the environment. However, there is no clear pattern with regard to the attribution of responsibility and the preferred policy approach. Finally, there is one small group of actors, coloured in purple in Fig. 3. Actors in this group all shared the belief that the agricultural sector is responsible for water contamination by pharmaceuticals.

Finally, we analysed the distribution of actor types across the identified actor groups. Normally, one would expect similar actors (such as different environmental organisations) to be more likely to share policy beliefs and to be part of one actor coalition. In fact, the type of actors is not a strong predictor of group membership. All actor groups are characterised by a heterogeneous composition regarding the types of actors. Furthermore, a differentiation between types of organisations did not reveal significant differences in their policy beliefs. In fact, the different types of organisations held surprisingly similar policy beliefs. The majority of organisations agreed that the discharge of pharmaceutical contaminants into aquatic ecosystems was primarily a problem of consumer behaviour that should be tackled by addressing consumption and disposal behaviour and upgrading wastewater treatment. This mirrors the control approach that is currently in place at the federal level and efforts of some German states to improve wastewater technologies on their territory.

Altogether, the qualitative analysis of the determined communities suggests that these did not represent adversarial actor coalitions. The identified actor groups diverged in their policy beliefs to some degree. However, an actor coalition that clearly mobilises for a major policy change could not be identified. The computation of a modularity score of 0.312 supports the interpretation that community structures in the network were not very strong. The modularity score ranges between -1 and 1 with higher modularity scores indicating stronger community structures [52]. The graphical layout by the Fruchterman-Reingold algorithm also supports this interpretation since many actors of the different communities were placed close to each other and communities partially overlap in the centre of the graph.

The supplemental materials provide the results of a robustness test for the graphical analysis where we gradually removed lower edge weights, i.e. edges between organisations with fewer shared policy preferences (Additional file 1: Annex B). These edges tend to mask underlying network structures. The robustness test further substantiates our findings on the coalition structure: even when we remove the edges with lower degree of similarity, organisations still cluster in one main group and then dissolve into many smaller subgroups.

To conclude, the results of the graphical analysis and the community detection point towards a unitary coalition structure as defined in the theoretical section. 


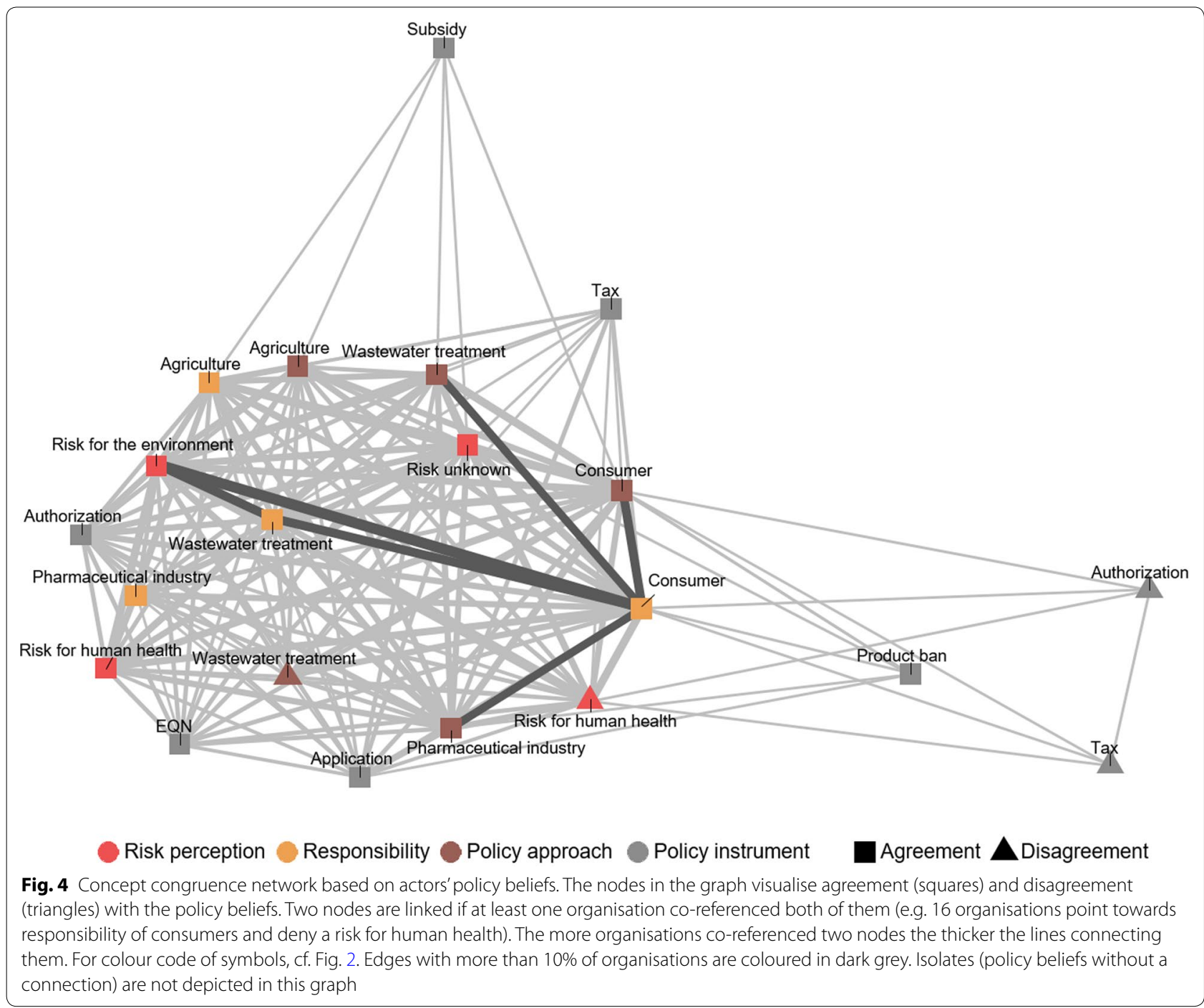

\section{Policy narratives in the policy debate}

The analysis of policy narratives substantiates our previous findings. Competing storylines in the policy debate on pharmaceutical contaminants in surface waters could not be identified. Figure 4 visualises the concept congruence network where two policy beliefs are linked by edges if they were co-referenced by at least one organisation. The more organisations co-referenced two policy beliefs the higher their similarity. The graph shows a similar unitary network structure we identified previously for the actor subtract network. There is only one big cluster in the centre with many edges connecting the different policy beliefs. We also performed a robustness test for the concept network where we gradually removed edges with lower similarity (i.e. fewer organisations). The unitary structure persisted, even when we normalised the network (Additional file 1: Annex C and D). The test also revealed that organisations not only mentioned the responsibility of consumers most frequently but also most often in combination with the following policy beliefs: responsibility of the wastewater treatment sector (15.5\% of organisations), policy approaches that address consumer behaviour (13.5\%), wastewater treatment $(11.0 \%)$, and the pharmaceutical industry $(10.0 \%)$ as well as a risk for the environment (17.0\%). The edges between these policy beliefs are coloured in grey in Fig. 4.

This combination of policy beliefs can be interpreted as the dominant narrative in the policy debate, which coincides to a large degree with the current water policy approach in place in Germany. The combination of consumer responsibility and a policy approach that targets the pharmaceutical industry is the only exception. Overall, the absence of a second cluster of policy beliefs indicates that the dominant policy narrative was not challenged by a competing storyline that could have advocated for policy change. 
Altogether, our empirical findings support our Expectation $1 \mathrm{~b}$. The policy status quo in the regulation of pharmaceutical contaminants in Germany has been characterised by a focus on a control approach that has been complemented by support for wastewater treatment upgrades and information campaigns for consumers in selected German states only. Implemented policy measures included mostly voluntary measures with 'soft' pressure on target groups. Over the course of time, a major policy change did not take place. The empirical findings on the public debate suggest that the observed coalition structures did not challenge but rather contributed to the persistence of the policy status quo. The debate was characterised by a unitary coalition structure without adversarial actor coalitions. Although identified actor groups showed some level of disagreement on whether the current control approach should be complemented by a stronger focus on end-of-pipe solutions, there was nearly no debate on how to implement the approach, i.e. policy measures, and whether the pressure on target groups should be increased. Thus, it was mainly the absence of an actor coalition publicly mobilising for major policy change that explains why the policy status quo has not been challenged.

\section{Discussion}

We can compare our findings to two strands of literature. The first includes studies on the relationship between public debates and policy change. The second involves public policy research on the policy subsystem of pharmaceutical contaminants and, on a more general level, on contaminants of emerging concern or micropollutants in water. Research in political science on pharmaceutical contaminants is very limited. However, a few empirical studies have been published on the topic of micropollutants or contaminants of emerging concern.

Several studies have identified polarisation of the public debate in a policy subsystem as an enhancing factor for subsequent major policy change. For instance, Leifeld [42] showed in a study on pension politics in Germany how a prior phase of polarisation in the public debate preceded major policy change. Similarly, Fisher et al. [20] investigated climate politics in the United States and showed, based on Congressional hearings, how a phase of polarisation and a subsequent phase of dominance of a climate change supporting actor coalition preceded the adoption of the first climate change bill in th 111th Congress. Rinscheid [72] was able to show for nuclear energy policy-making that, similarly to our case, a unitary coalition structure inhibited major policy change in Japan in the aftermath of the nuclear crisis after the Fukushima accident. On the contrary, a polarised coalition structure enhanced major policy change in
Germany. Thus, our findings are in line with literatue that investigates the relationship between public debate and (the absence of) policy change.

The level of belief similarity among political actors was surprisingly high. Normally, there are significant differences in policy beliefs between political actors in areas of environmental policy $[29,88,89]$. One possible explanation revolves around the character of the policy issue. The issue of pharmaceutical contaminants is complex and characterised by a high degree of uncertainty with regard to consequences [34]. The complexity of the issue implies that there is not the one solution able to solve the problem [35], which might explain why actors with an interest in stronger environmental protection do not mobilise for a certain policy solution or policy approach. In fact, Metz and Leifeld [57] and Metz et al. [58] observe a similar pattern in a study on the regulation of micropollutants in Switzerland. They find that environmental organisations, as well as other actors such as water associations, do not prefer specific policy solutions but take a positive stance towards most types of policy intervention that would help to improve water protection. Metz [56] also investigates political actors' policy beliefs in Germany during the drafting of the OGewV between 2008 and 2011 based on survey data. She also finds comparatively high similarity in actors' policy beliefs on the issue of micropollution, which further supports our observation that the policy subsystem is characterised by an absence of strong conflict lines. Schaub and Metz [80] more systematically compare coalition structures in the policy subsystem of micropollutants in Germany. The authors compare two different types of data used to measure policy beliefs, survey and media data, and show that the analysis of both data sources lead to the identification of a policy subsystem characterised by a similar unitary coalition structure.

Compared to other policy issues, media attention to the issue of pharmaceutical contaminants was lower. For instance, the issue of fracking received about twice as much attention in the FAZ in a similar time period [88]. In general, policy issues compete for attention [99]. The complex and often very technical nature of the issue of pharmaceutical contaminants could be a barrier for increased attention, for instance by political parties. This also could be an explanation why the Green party was not more active in the public debate and did not pursue a more coherent mobilisation strategy with a stronger focus on stricter and source-directed policy measures. Similarly, environmental organisations are confronted with many environmental issues and might lack the resources to run sophisticated public campaigns on every single issue, especially if these are complex and technical in nature. Related to this point, these actors might prefer other venues, such as stakeholder consultations, in their 
attempt to influence policy on pharmaceutical contaminants. In principle, the stakeholder consultation initiated by the German Federal Ministry of the Environment in 2016 provided such a venue. It should also be kept in mind that -at least at the scientific and technological levels-intensive internal technical discussions take place. For instance, a scientific discussion about the best strategy for the enforcement of wastewater treatment plants has been initiated quite a while ago and is ongoing at a world-wide scale (for examples, see [6, 12, 23, 24, 54, $55,60,102]$. However, it remains questionable whether stakeholder consultations and non-public scientific discussions will lead to a change in the policy response to pharmaceutical contaminants. Unfortunately, the results of the federal stakeholder dialogue published in 2019 cement a continuation of the current policy approach. The disillusioning outcome suggests that future regulations on pharmaceutical contaminants in Germany are likely to remain 'soft' despite claims from the scientific community that the current control approach should be complemented by an and end-of-pipe and a sourcedirected approach [27] and that a mix of policy instruments would be favourable for achieving environmental goals $[11,68]$.

The low level of politisation of the public debate might also coincide with the strong presence of politicaladministrative actors. Their high activity in the public debate suggests that agenda-setting took place top-down to a large degree. Federal and state ministries and agencies, such as the Federal Ministry of the Environment or the German Environment Agency, apparently concluded that this particular issue needed to be addressed and, therefore, initiated a policy-making process. The federal stakeholder consultation may serve as an example for such a top-down agenda-setting process. Similar top-down activities could be observed in some German states, including Baden-Württemberg [121, 122], Hessen [116], and North Rhine-Westphalia [117]. In contrast, politicised public debates often coincide with bottom-up agenda-setting. In this case, political actors, e.g. environmental organisations or citizen initiatives, try to create attention for an issue in order to place the issue on the political agenda $[4,31,91]$. The comparatively low presence of organisations with an interest in environmental protection, e.g. environmental organisations or the Green party (e.g. compared to [61] or [89]), in the public debate suggests that bottom-up agenda-setting was weak in comparison. However, it is bottom-up agendasetting that mostly leads to major policy change whereas top-down agenda-setting is rather associated with only small incremental changes [4]. These findings also resonate with Metz [56] who finds that the Federal Ministry of the Environment, the German Environment Agency and representatives of the German states played central roles in the formulation of the $\mathrm{OGewV}$, which in turn was largely motivated by policy-making at the EU-level [56].

\section{Conclusions}

Despite clear-cut scientific evidence that pharmaceutical contaminants cause adverse effects in aquatic life and pose a risk for drinking water resources, the regulatory response in Germany has been weak. This study investigated the impact of the public debate on the policy response to pharmaceutical contaminants in surface waters in Germany. Thus, the study contributes to public policy research in environmental policy. More specifically, it contributes to literature on pharmaceutical contaminants in water by analysing current regulation and policy-making processes in this policy subsystem with a political science research design, coupled with insights from the environmental sciences. The main aim was to investigate whether the public debate on pharmaceutical contaminants had an impact on the observed policy response to pharmaceutical contaminants in Germany. Overall, the empirical findings suggest that the observed actor coalition structures revealed in the public debate contributed to the persistence of the regulatory response. Strong bottom-up mobilisation by an adversarial coalition could not be observed. Reasons could be the complex and technical nature of the policy issue, which makes it more difficult to conduct sophisticated public campaigns. Related to this, political actors with an interest in policy change might resort to other venues, such as lobbying or stakeholder consultations, to influence policy-making on the regulation of pharmaceutical contaminants. Our findings suggest that policy formation was largely influenced by top-down agenda-setting by political-administrative actors, instead. Based on our findings and the insights of previous research, we expect only small incremental changes to the current regulatory response likely to occur in the near future. Nevertheless, empirical research in political science has repeatedly shown that the public debate can have an impact on policy formation and trigger major policy change. Thus, political actors with an interest in stricter regulatory measures and a prioritisation of source-directed approaches might want to reconsider their strategies.

Despite the insights offered, the current study bears some limitations: First, the findings of this case study do not allow causal conclusions, since the study has exclusively been focused on Germany and, therefore, lacks comparison with other cases. Future studies might build on the results of this pre-test and compare different cases, which would allow to systematically vary the independent variable and control for other influences. A comparison with Switzerland appears fruitful where the adoption 
of the new Water Protection Act in 2016 meant a change to an-end-of-pipe approach combined with strong regulatory measures. Selected operators have been forced to upgrade their purification technologies to the so-called "fourth treatment stage" over the next 20 years [56]. Second, the study focuses on the role of the public debate and neglects other venues political actors might use to influence policy-making. Other venues may include lobbying activities behind closed doors, stakeholder consultations or legal confrontations. Further studies could investigate the strategic behaviour of specific political actors based on interviews, for instance. Third, we had to leave other potentially influential factors aside. These factors include the role of the EU or the influence of the German states in Germany's federal political system. Future studies might, e.g. investigate long-term and longrange EU policy-making processes and their impact on national responses to pharmaceutical contaminants.

\section{Supplementary information}

Supplementary information accompanies this paper at https://doi. org/10.1186/s12302-020-00423-5.

Additional file 1. Supplemental materials.

\section{Abbreviations}

CECs: Contaminants of Emerging Concern; EQS: Environmental Quality Standard; EU: European Union; FAZ: Frankfurter Allgemeine Zeitung; OGewV: German Surface Water Ordinance; WHG: Federal Water Act.

\section{Acknowledgements \\ The authors are especially grateful to Andreas Fleig for his contribution to this study. We also thank Felix Reimann and Linda Behrisch for research assistance in coding the network data. Special thanks are due to all members of the Effect-Net project consortium for valuable feedback: Michel Barnet, Rebecca Bauer, Frank Bergmann, Gerald Brenner-Weiß, Thomas Dickmeis, Peter Fechner, Siegfried Hohmann, Carolin Huhn, Stefanie Jakob, Sarah Knoll, Ursula Kummer, Melanie Macherey, Susanna Mieck, Günther Proll, Jutta-Schneider-Rapp, Eike Rogall, Andrea Schink, Thomas Schwartz, Selina Tisler, Jale Tosun, Rita Trieb- skorn, Christian Zwiener, Michael Ziegler and Florian Zindler.}

\section{Authors' contributions}

SS: conceptualisation, data curation, formal analysis, investigation, visualisation, writing —original draft. TB: conceptualisation, visualisation, writing —original draft, editing. All authors read and approved the final manuscript.

\section{Funding}

This study is a contribution to the joint project "Effect-Net in Water Research" supported within the framework of the Water Research funding program ("Wassernetzwerk") of the State of Baden-Wuerttemberg. The authors would like to thank the Ministerium für Wissenschaft, Forschung und Kunst BadenWürttemberg for the generous financial support (AZ 33-7533-25-11/37/6).

\section{Availability of data and materials}

Due to copyright we are not allowed to store the retrieved newspaper articles in publicly available repositories. However, the media data used in this study will be made available upon request.

\section{Ethics approva}

Not applicable.
Consent for publication

Not applicable.

\section{Competing interests}

The authors declare no competing interests.

\section{Author details}

${ }^{1}$ Institute of Political Science, Heidelberg University, Bergheimer Straße 58, 69115 Heidelberg, Germany. ${ }^{2}$ Aquatic Ecology and Toxicology Section, Centre for Organismal Studies, Heidelberg University, Im Neuenheimer Feld 504, Heidelberg, Germany.

Received: 29 June 2020 Accepted: 7 October 2020

Published online: 20 October 2020

\section{References}

1. Adeel M, Song X, Wang Y, Francis D, Yang Y (2017) Environmental impact of estrogens on human, animal and plant life: a critical review. Environ Int 99:107-119. https://doi.org/10.1016/j.envint.2016.12.010

2. Barranco J, Wisler D (1999) Validity and systematicity of newspaper data in event analysis. Eur Sociol Rev 15:301-322. https://doi.org/10.1093/ oxfordjournals.esr.a018265

3. Baumgartner FR, Jones BD (1991) Agenda dynamics and policy subsystems. J Politics 53:1044-1074

4. Baumgartner FR, Jones BD (2009) Agendas and instability in American politics, second edition. Chicago studies in American politics. The University of Chicago Press, Chicago

5. Beek T, Weber F-A, Bergmann A, Hickmann S, Ebert I, Hein A, Küster A (2016) Pharmaceuticals in the environment-global occurrences and perspectives. Environ Toxicol Chem 35:823-835. https://doi. org/10.1002/etc.3339

6. Beijer K, Björlenius B, Shaik S, Lindberg RH, Brunström B, Brandt I (2017) Removal of pharmaceuticals and unspecified contaminants in sewage treatment effluents by activated carbon filtration and ozonation: evaluation using biomarker responses and chemical analysis. Chemosphere 176:342-351. https://doi.org/10.1016/j.chemosphere.2017.02.127

7. Berger $H$ (2017) The authority of German states in water law [Die Länderkompetenz im Wasserrecht]. Zeitschrift für Landesverfassungsrecht und Landesverwaltungsrecht 2:4-11

8. Binzer Hobolt S, Klemmensen R (2008) Government responsiveness and political competition in comparative perspective. Comp Political Studies 41:309-337. https://doi.org/10.1177/0010414006297169

9. Blondel VD, Guillaume J-L, Lambiotte R, Lefebvre E (2008) Fast unfolding of communities in large networks. J Stat Mech Theory Exp 2008:P10008. https://doi.org/10.1088/1742-5468/2008/10/P10008

10. BraunbeckT, Brauns A, Keiter S, Hollert H, Schwartz P (2009) Fish populations under stress - the example of the Lower Neckar [Fischpopulationen unter Stress-das Beispiel des Unteren Neckars]. Umweltwissenschaften und Schadstoffforschung 21:197-211. https://doi.org/10.1007/ s12302-009-0044-6

11. Bressers HTA, O'Toole LJ Jr (2005) Instrument selection and implementation in a networked context. In: Eliadis P, Hill MM, Howlett M (eds) Designing government: from instruments to governance. McGillQueen's Press-MQUP, Montreal, pp 132-153

12. Brillas E (2020) A review on the photoelectro-Fenton process as efficient electrochemical advanced oxidation for wastewater remediation. Treatment with UV light, sunlight, and coupling with conventional and other photo-assisted advanced technologies. Chemosphere 250:126198. https://doi.org/10.1016/j.chemosphere.2020.126198

13. Burkhardt-Holm P, Giger W, Guttinger H, Ochsenbein U, Peter A, Scheurer K, Segner H, Staub E, Suter MJ-F (2005) Where have all the fish gone? The reasons why fish catches in Swiss rivers are declining. Environ Sci Technol 39:441-447

14. Cook PM, Robbins JA, Endicott DD, Lodge KB, Guiney PD, Walker MK, Zabel EW, Peterson RE (2003) Effects of aryl hydrocarbon receptormediated early life stage toxicity on lake trout populations in Lake Ontario during the 20th century. Environ Sci Technol 37:3864-3877. https://doi.org/10.1021/es034045m 
15. Crawford SE, Hartung T, Hollert H, Mathes B, van Ravenzwaay B, StegerHartmann T, Studer C, Krug HF (2017) Green toxicology: a strategy for sustainable chemical and material development. Environ Sci Eur 29:16. https://doi.org/10.1186/s12302-017-0115-z

16. Desbiolles F, Malleret L, Tiliacos C, Wong-Wah-Chung P, Laffont-Schwob I (2018) Occurrence and ecotoxicological assessment of pharmaceuticals: Is there a risk for the Mediterranean aquatic environment? Sci Total Environ 639:1334-1348. https://doi.org/10.1016/j.scitotenv.2018.04.351

17. Ebele AJ, Abou-Elwafa Abdallah M, Harrad S (2017) Pharmaceuticals and personal care products (PPCPS) in the freshwater aquatic environment. Emerg Contam 3:1-16. https://doi.org/10.1016/j.emcon .2016 .12 .004

18. Fabbri E (2015) Pharmaceuticals in the environment: expected and unexpected effects on aquatic fauna. Ann NY Acad Sci 1340:20-28. https://doi.org/10.1111/nyas.12605

19. Fisher PMJ, Borland R (2003) Gauging the pharmaceutical burden on Sydney's environment: a preventative response. J Clean Prod 11:315-320. https://doi.org/10.1016/S0959-6526(02)00048-3

20. Fisher DR, Leifeld P, Iwaki Y (2013) Mapping the ideological networks of American climate politics. Clim Chang 116:523-545. https://doi. org/10.1007/s10584-012-0512-7

21. Fruchterman TMJ, Reingold EM (1991) Graph drawing by force-directed placement. Softw Practice Exp 21:1129-1164. https://doi.org/10.1002/ spe. 4380211102

22. Gaw S, Thomas KV, Hutchinson TH (2014) Sources, impacts and trends of pharmaceuticals in the marine and coastal environment. Philos Trans Royal Soc B Biol Sci. https://doi.org/10.1098/rstb.2013.0572

23. Guillossou R, Le Roux J, Mailler R, Pereira-Derome CS, Varrault G, Bressy A, Vulliet E, Morlay C, Nauleau F, Rocher V, Gasperi J (2020) Influence of dissolved organic matter on the removal of 12 organic micropollutants from wastewater effluent by powdered activated carbon adsorption. Water Res 172:115487. https://doi.org/10.1016/j.watres.2020.115487

24. Henneberg A, Triebskorn R (2015) Efficiency of advanced wastewater treatment technologies for the reduction of hormonal activity in effluents and connected surface water bodies by means of vitellogenin analyses in rainbow trout (Oncorhynchus mykiss) and brown trout (Salmo trutta f. fario). Environ Sci Eur 27:22. https://doi.org/10.1186/ s12302-015-0056-3

25. Herzog LMJ (2020) Micro-pollutant regulation in the River Rhine. Springer International Publishing, Cham

26. Hillenbrand T, Tettenborn F, Menger-Krug E, Marscheider-Weidemann F, Fuchs S, Toshovski S, Kittlaus S, Metzger S, Tjoeng I, Wermter P, Kersting M, Abegglen C (2015) Measures to reduce the entry of micropollutants into surface water [Maßnahmen zur Verminderung des Eintrages von Mikroschadstoffen in die Gewässer], Dessau-Roßlau. https://www. umweltbundesamt.de/sites/default/files/medien/378/publikationen/ texte_85_2014_massnahmen_zur_verminderung_des_eintrages_von_ mikroschadstoffen_in_die_gewaesser_0.pdf. Accessed 23 Sept 2020

27. Hillenbrand T, Tettenborn F, Fuchs S, Toshovski S, Metzger S, Tjoeng I, Wermter P, Kersting M, Hecht D, Werbeck N, Wunderlin P (2016) Measures to reduce the entry of micropollutants into surface water-Phase $2[\mathrm{Ma}$ ßnahmen zur Verminderung des Eintrages von Mikroschadstoffen in die Gewässer-Phase 2], Dessau-Roßlau. https://www.umweltbund esamt.de/sites/default/files/medien/377/publikationen/mikroschad stoffen_in_die_gewasser-phase_2.pdf. Accessed 23 Sept 2020

28. Howlett M, Ramesh M (1998) Policy subsystem configurations and policy change: operationalizing the postpositivist analysis of the politics of the policy process. Policy Stud J 26:466-481. https://doi. org/10.1111/j.1541-0072.1998.tb01913.x

29. Ingold K (2011) Network structures within policy processes: coalitions, power, and brokerage in Swiss climate policy. Policy Stud J 39:435-459. https://doi.org/10.1111/j.1541-0072.2011.00416.x

30. Ingold K, Gschwend M (2014) Science in policy-making: neutral experts or strategic policy-makers? West European Polit 37:993-1018. https:// doi.org/10.1080/01402382.2014.920983

31. Jones BD, Baumgartner FR (2007) The politics of attention: how government prioritizes problems. University of Chicago Press, Chicago

32. Kar S, Sanderson H, Roy K, Benfenati E, Leszczynski J (2020) Ecotoxicological assessment of pharmaceuticals and personal care products using predictive toxicology approaches. Green Chem 35:823. https:// doi.org/10.1039/C9GC03265G
33. Keiter S, Böttcher M, Grund S, Seitz N, Braunbeck T, Hollert H (2009) Declining fish populations in the Upper Donau [Der Fischrückgang in der oberen Donau]. Umweltwissenschaften und Schadstoffforschung 21:186-196. https://doi.org/10.1007/s12302-009-0040-x

34. Kirschke S, Borchardt D, Newig J (2017) Mapping complexity in environmental governance: a comparative analysis of 37 priority issues in German water management. Environ Policy Gov 27:534-559. https:// doi.org/10.1002/eet.1778

35. Kirschke S, Franke C, Newig J, Borchardt D (2019) Clusters of water governance problems and their effects on policy delivery. Policy Soc 2:1-23. https://doi.org/10.1080/14494035.2019.1586081

36. Klatte S, Schaefer H-C, Hempel M (2017) Pharmaceuticals in the environment - A short review on options to minimize the exposure of humans, animals and ecosystems. Sustain Chem Pharm 5:61-66. https ://doi.org/10.1016/j.scp.2016.07.001

37. Knill C, Tosun J (2020) Public policy: a new introduction, 2nd edn. Macmillan Education, London

38. Kümmerer K (2007) Sustainable from the very beginning: rational design of molecules by life cycle engineering as an important approach for green pharmacy and green chemistry. Green Chem 9:899. https:// doi.org/10.1039/b618298b

39. Kümmerer K, Hempel M (2010) Green and sustainable pharmacy. Springer, Berlin, Heidelberg

40. Kümmerer K, Dionysiou DD, Olsson O, Fatta-Kassinos D (2019) Reducing aquatic micropollutants-increasing the focus on input prevention and integrated emission management. Sci Total Environ 652:836-850. https ://doi.org/10.1016/j.scitotenv.2018.10.219

41. Küster A, Adler N (2014) Pharmaceuticals in the environment: scientific evidence of risks and its regulation. Philos Trans Royal Soc B Biol Sci. https://doi.org/10.1098/rstb.2013.0587

42. Leifeld P (2013) Reconceptualizing major policy change in the advocacy coalition framework: a discourse network analysis of German pension politics. Policy Stud J 41:169-198. https://doi.org/10.1111/ psj. 12007

43. Leifeld P (2016) Policy debates as dynamic networks: German pension politics and privatization discourse. Campus Verlag, Frankfurt

44. Leifeld P (2017) Discourse network analysis: Policy debates as dynamic networks. In: Victor JN, Montgomery AH, Lubell M (eds) The oxford handbook of political networks. Oxford University Press, Oxford, pp $301-325$

45. Leifeld P (2020) Policy debates and discourse network analysis: A research agenda. PaG 8:180. https://doi.org/10.17645/pag.v8i2.3249

46. Leifeld P, Brandenberger L (2019) Endogenous coalition formation in policy debates. https://arxiv.org/pdf/1904.05327v1

47. Leifeld P, Gruber J, Bossner FR (2019) Discourse network analyzer manual: Version 20-beta24jar with rDNA 2116. University of Essex, Colchester

48. Lemaire $D(1998)$ Regulation as a tool of government. In: BemelmansVidec M-L, Rist R, Vedung E (eds) Carrots, sticks and sermons: policy instruments and their evaluation. Transaction Publishers, London, pp 59-76

49. Levy JS (2008) Case studies: types, designs, and logics of inference. Confl Manag Peace Sci 25:1-18. https://doi.org/10.1080/0738894070 1860318

50. Leydesdorff $L$ (2008) On the normalization and visualization of author co-citation data: Salton's Cosineversus the Jaccard index. J Am Soc Inform Sci Technol 59:77-85. https://doi.org/10.1002/asi.20732

51. Li Y, Taggart MA, McKenzie C, Zhang Z, Lu Y, Pap S, Gibb S (2019) Utilizing low-cost natural waste for the removal of pharmaceuticals from water: Mechanisms, isotherms and kinetics at low concentrations. J Clean Prod 227:88-97. https://doi.org/10.1016/j.jclepro.2019.04.081

52. Linhares CDG, Ponciano JR, Pereira FSF, Rocha LEC, Paiva JGS, Travençolo BAN (2020) Visual analysis for evaluation of community detection algorithms. Multimed Tools Appl 79:17645-17667. https://doi. org/10.1007/s11042-020-08700-4

53. Lonappan L, Brar SK, Das RK, Verma M, Surampalli RY (2016) Diclofenac and its transformation products: environmental occurrence and toxicity—a review. Environ Int 96:127-138. https://doi.org/10.1016/j. envint.2016.09.014

54. López-Velázquez K, Villanueva-Rodríquez M, Mejía-González G, HerreraLópez D (2020) Removal of 17a-ethinylestradiol and caffeine from 
wastewater by UASB-Fenton coupled system. Environ Technol. https:// doi.org/10.1080/09593330.2020.1740799

55. Maier D, Benisek M, Blaha L, Dondero F, Giesy JP, Köhler H-R, Richter D, Scheurer M, Triebskorn R (2016) Reduction of dioxin-like toxicity in effluents by additional wastewater treatment and related effects in fish. Ecotoxicol Environ Saf 132:47-58. https://doi.org/10.1016/j.ecoen v.2016.04.036

56. Metz F (2017) From network structure to policy design in water protection: a comparative perspective on micropollutants in the Rhine River riparian countries. Springer International Publishing, Cham

57. Metz F, Leifeld P (2018) Governing water with market-based instruments: preferences and skepticism in Switzerland. In: Bréthaut C, Schweizer R (eds) A critical approach to international water management trends. Palgrave Macmillan UK, London, pp 147-176

58. Metz F, Leifeld P, Ingold K (2018) Interdependent policy instrument preferences: a two-mode network approach. J Public Policy 89:1-28. https://doi.org/10.1017/S0143814X18000181

59. Mezzelani M, Gorbi S, Regoli F (2018) Pharmaceuticals in the aquatic environments: evidence of emerged threat and future challenges for marine organisms. Marine Environ Res 140:41-60. https://doi. org/10.1016/j.marenvres.2018.05.001

60. Monteoliva-García A, Martín-Pascual J, Muñío MM, Poyatos JM (2020) Effects of carrier addition on water quality and pharmaceutical removal capacity of a membrane bioreactor-advanced oxidation process combined treatment. Sci Total Environ 708:135104. https://doi. org/10.1016/j.scitotenv.2019.135104

61. Nagel M (2016) Polarisation in the political discourse? [Polarisierung im politischen Diskurs?]. Springer Fachmedien Wiesbaden, Wiesbaden

62. Nkoom M, Lu G, Liu J (2018) Occurrence and ecological risk assessment of pharmaceuticals and personal care products in Taihu Lake, China: a review. Environ Sci Process Impacts 20:1640-1648. https://doi. org/10.1039/C8EM00327K

63. Oaks JL, Gilbert M, Virani MZ, Watson RT, Meteyer CU, Rideout BA, Shivaprasad HL, Ahmed S, Chaudhry MJl, Arshad M, Mahmood S, Ali A, Khan AA (2004) Diclofenac residues as the cause of vulture population decline in Pakistan. Nature 427:630-633. https://doi.org/10.1038/natur e02317

64. Oelkers K, Floeter C (2019) The accessibility of data on environmental risk assessment of pharmaceuticals: Is the marketing authorisation procedure in conflict with the international right of access to environmental information? Environ Sci Eur. https://doi.org/10.1186/s1230 2-019-0256-3

65. Ognyanova K (2016) Network Analysis and Visualization with R and igraph: NetSciX 2016 School of Code Workshop, Wroclaw, Poland. https ://kateto.net/wp-content/uploads/2016/01/NetSciX_2016_Workshop. pdf. Accessed 22 Sept 2020

66. Olmstead SM (2010) The economics of water quality. Rev Environ Econ Policy 4:44-62. https://doi.org/10.1093/reep/rep016

67. Osička J, Lehotský L, Zapletalová V, Černoch F, Dančák B (2018) Natural gas market integration in the Visegrad 4 region: an example to follow or to avoid? Energy Policy 112:184-197. https://doi.org/10.1016/j.enpol .2017.10.018

68. Pakizer K, Fischer M, Lieberherr E (2020) Policy instrument mixes for operating modular technology within hybrid water systems. Environ Sci Policy 105:120-133. https://doi.org/10.1016/j.envsci.2019.12.009

69. Patel M, Kumar R, Kishor K, Mlsna T, Pittman CU, Mohan D (2019) Pharmaceuticals of emerging concern in aquatic systems: chemistry, occurrence, effects, and removal methods. Chem Rev 119:3510-3673. https://doi.org/10.1021/acs.chemrev.8b00299

70. Peters M (2013) The democratic function of the public sphere in Europe. German Law J 14:673-693. https://doi.org/10.1017/S2071 832200001978

71. Rastogi T, Leder C, Kümmerer K (2015) Re-designing of existing pharmaceuticals for environmental biodegradability: a tiered approach with $\beta$-blocker propranolol as an example. Environ Sci Technol 49:1175611763. https://doi.org/10.1021/acs.est.5b03051

72. Rinscheid A (2015) Crisis, policy discourse, and major policy change: exploring the role of subsystem polarization in nuclear energy policymaking. Eur Policy Anal 1:34-70
73. Rinscheid A (2020) Business power in noisy politics: an exploration based on discourse network analysis and survey data. PaG 8:286-297. https://doi.org/10.17645/pag.v8i2.2580

74. Rogall ET, Jacob S, Triebskorn R, Schwartz T (2020) The impact of the anti-diabetic drug metformin on the intestinal microbiome of larval brown trout (Salmo trutta f. fario). Environ Sci Eur. https://doi. org/10.1186/s12302-020-00341-6

75. Rogers P, de Silva R, Bhatia R (2002) Water is an economic good: How to use prices to promote equity, efficiency, and sustainability. Water Policy 4:1-17

76. Sabatier PA (1987) Knowledge, policy-oriented learning, and policy change. Knowledge 8:649-692

77. Sabatier PA (1998) The advocacy coalition framework: revisions and relevance for Europe. J Eur Public Policy 5:98-130

78. Sabatier PA, Jenkins-Smith HC (1999) The advocacy coalition framework: an assessment. In: Sabatier PA (ed) Theories of the policy process. Westview Press, Boulder CO, pp 117-166

79. Santos D, Luzio A, Coimbra AM (2017) Zebrafish sex differentiation and gonad development: a review on the impact of environmental factors. Aquat Toxicol 191:141-163. https://doi.org/10.1016/j.aquat ox.2017.08.005

80. Schaub S, Metz F (2020) Comparing discourse and policy network approaches: Evidence from water policy on micropollutants. Politics Gov 8:184. https://doi.org/10.17645/pag.v8i2.2597

81. Shanahan EA, Jones MD, McBeth MK (2011) Policy narratives and policy processes. Policy Stud J 39:535-561. https://doi.org/10.111 1/j.1541-0072.2011.00420.x

82. Soroka SN, Wlezien C (2005) Opinion-policy dynamics: public preferences and public expenditure in the United Kingdom. Br J Political Sci 35:665-689. https://doi.org/10.1017/50007123405000347

83. Soroka SN, Wlezien C (2009) Degrees of democracy. Cambridge University Press, Cambridge

84. Strøm K (1990) A behavioral theory of competitive political parties. Am J Political Sci 34:565. https://doi.org/10.2307/2111461

85. Stülten D, Zühlke S, Lamshöft M, Spiteller M (2008) Occurrence of diclofenac and selected metabolites in sewage effluents. Sci Total Environ 405:310-316. https://doi.org/10.1016/j.scitotenv.2008.05.036

86. Ternes TA, Joss A, Siegrist H (2004) Peer reviewed: scrutinizing pharmaceuticals and personal care products in wastewater treatment. Environ SciTechnol 38:392A-399A

87. Tosun J (2013) How the EU handles uncertain risks: understanding the role of the precautionary principle. J Eur Public Policy 20:1517-1528. https://doi.org/10.1080/13501763.2013.834549

88. Tosun J, Lang A (2016) The Politics of hydraulic fracturing in Germany: party competition at different levels of government. In: Weible CM, Heikkila T, Ingold K, Fischer M (eds) Policy debates on hydraulic fracturing. Palgrave Macmillan US, New York, pp 177-200

89. Tosun J, Schaub S (2017) Mobilization in the European public sphere: the struggle over genetically modified organisms. Rev Policy Res 34:310-330

90. Tosun J, Scherer U (2020) Attention and water governance: an agendasetting perspective. Water 12(8):2138

91. Tosun J, Triebskorn R (2020) Civil Society and the Governance of Water Services: German Political Parties' Reactions to Right2Water. Water 12:743. https://doi.org/10.3390/w12030743

92. Tosun J, Varone F (2020) Politicizing the use of glyphosate in Europe: Comparing policy issue linkage across advocacy organisations and countries. J Comp Policy Anal Res Prac. https://doi.org/10.1080/13876 988.2020.1762076

93. Tosun J, Schaub S, Fleig A (2020) What determines regulatory preferences? Insights from micropollutants in surface waters. Environ Sci Policy 106:136-144

94. Tosun J, Scherer U, Schaub S, Horn H (2020) Making Europe go from bottles to the tap: Political and societal attempts to induce behavioural change. WIREs Water. https://doi.org/10.1002/wat2.1435

95. Triebskorn R, Casper H, Scheil V, Schwaiger J (2007) Ultrastructural effects of pharmaceuticals (carbamazepine, clofibric acid, metoprolol, diclofenac) in rainbow trout (Oncorhynchus mykiss) and common carp (Cyprinus carpio). Anal Bioanal Chem 387:1405-1416. https://doi. org/10.1007/s00216-006-1033-x 
96. Triebskorn R, Blaha L, Gallert C, Giebner S, Hetzenauer H, Köhler H-R, Kuch B, Lüddeke F, Oehlmann J, Peschke K, Sacher F, Scheurer M, Schwarz S, Thellmann P, Wurm K, Wilhelm S (2019) Freshwater ecosystems profit from activated carbon-based wastewater treatment across various levels of biological organisation in a short timeframe. Environ Sci Eur 31:20. https:// doi.org/10.1186/s12302-019-0267-0

97. Varone F, Ingold K, Jourdain C (2017) Defending the status quo across venues and coalitions: evidence from California interest groups. J Public Policy 37:1-26. https://doi.org/10.1017/S0143814X16000179

98. Vidal-Dorsch DE, Bay SM, Maruya K, Snyder SA, Trenholm RA, Vanderford BJ (2012) Contaminants of emerging concern in municipal wastewater effluents and marine receiving water. Environ Toxicol Chem 31:2674-2682. https://doi.org/10.1002/etc.2004

99. Wagner M, Meyer TM (2014) Which issues do parties emphasise? Salience strategies and party organisation in multiparty systems. West Eur Politics 37:1019-1045. https://doi.org/10.1080/01402382.2014.911483

100. Weible CM, Sabatier PA (2009) Coalitions, science, and belief change: comparing adversarial and collaborative policy subsystems. Policy Stud 37:195-212. https://doi.org/10.1111/j.1541-0072.2009.00310.x

101. Weiss JA, Tschirhart M (1994) Public information campaigns as policy instruments. J Policy Anal Manag 13:82. https://doi.org/10.2307/3325092

102. Yang Y, Ok YS, Kim K-H, Kwon EE, Tsang YF (2017) Occurrences and removal of pharmaceuticals and personal care products (PPCPS) in drinking water and water/sewage treatment plants: a review. Sci Total Environ 596-597:303-320. https://doi.org/10.1016/j.scitotenv.2017.04.102

103. Zhao X, Grimes KL, Colosi LM, Lung W-S (2019) Attenuation, transport, and management of estrogens: a review. Chemosphere 230:462-478. https:// doi.org/10.1016/j.chemosphere.2019.05.086

\section{Legal documents}

104. Commission Implementing Decision (EU) 2015/495 of 20 March 2015 establishing a watch list of substances for Union-wide monitoring in the field of water policy pursuant to Directive 2008/105/EC of the European Parliament and of the Council (2015) Off J L78, pp. 40-42

105. Commission Implementing Decision (EU) 2018/840 of 5 June 2018 establishing a watch list of substances for Union-wide monitoring in the field of water policy pursuant to Directive 2008/105/EC of the European Parliament and of the Council and repealing Commission Implementing Decision (EU) 2015/495 (2018) Off J L141, pp. 9-12

106. Directive 2000/60/EC of the European Parliament and of the Council of 23 October 2000 establishing a framework for Community action in the field of water policy (2000) Off J L327, pp. 1-73

107. Directive 2001/83/EC of the European Parliament and of the Council of 6 November 2001 of the Community code relating to medicinal products for human use (2001) Off J L311, pp. 67-188

108. Directive 2008/105/EC of the European Parliament and of the Council of 16 December 2008 on environmental quality standards in the field of water policy, amending and subsequently repealing Council Directives 82/176/ EEC, 83/513/EEC, 84/156/EEC, 84/491/EEC, 86/280/EEC and amending Directive 2000/60/EC of the European Parliament and of the Council (2008) Off J L348, pp. 84-97

109. Directive 2013/39/EU of the European Parliament and the Council of 12 August 2013 amending Directives 2000/60/EC and 2008/105/EC as regards priority substances in the field of water policy (2013) Off J L226, pp. 1-17

110. Gesetz über den Verkehr mit Arzneimitteln in der Fassung der Bekanntmachung vom 12. Dezember 2005 (2005), BGBI Part I, p. 3394

111. OGewV (Oberflächengewässerverordnung) vom 20. Juni 2016 (BGBI. IS. 1373), die durch Artikel 255 der Verordnung vom 19. Juni 2020 (BGBI. I S. 1328) geändert worden ist
112. Regulation (EC) No 726/2004 of the European Parliament and of the Council of 31 March 2004 laying down Community procedures for the authorisation and supervision of medicinal products for human and veterinary use and establishing a European Medicines Agency (2004) Off J L136, pp. 1-121

113. WHG (Wasserhaushaltsgesetz) vom 31. Juli 2009 (BGBI. I S. 2585), das zuletzt durch Artikel 1 des Gesetzes vom 19. Juni 2020 (BGBI. I S. 1408) geändert worden istGovernment documents

114. European Environment Agency (2018) European waters: Assessment of status and pressures (2018) EEA Report, no 2018,7. Publications Office of the European Union, Luxembourg

115. Federal Ministry for the Environment, Nature Conservation and Nuclear Safety/Federal Environment Agency (2019) Final report: Outcome of the 2nd phase of the stakeholder dialogue on the federal »micropollution strategy« to implement measures to reduce the entry of micropollutants in waters [Ergebnispapier: Ergebnisse der Phase 2 des Stakeholder-Dialogs »Spurenstoffstrategie des Bundes zur Umsetzung von Maßnahmen für die Reduktion von Spurenstoffeinträgen in die Gewässer]. https://www.bmu. de/download/ergebnisse-der-phase-2-des-stakeholder-dialogs-spurenstoffstrategie-des-bundes/. Accessed 7 April 2020

116. HMUKLV (2018) Spurenstoffstrategie Hessisches Ried. https://umwelt.hessen.de/sites/default/files/media/hmuelv/spurenstoffstrategie_hessisches_ ried_vom_2018_04_30_auflage_02.pdf. Accessed 23 September 2020

117. MULNV NRW (2012) Programm Reine Ruhr. zur Strategie einer nachhaltigen Verbesserung der Gewässer- und Trinkwasserqualität in Nordrhein-Westfalen. https:/taz.de/fileadmin/static/pdf/ProgrammReineRuhrBerichtFINAL. pdf. Accessed 23 September 2020

118. MULNV NRW (2019) Erfolgreiche Sensibilisierung: Kampagne „Essen macht's klar" zeigt Wirkung. https://www.land.nrw/de/pressemitteilung/erfolgreiche-sensibilisierung-kampagne-essen-machts-klar-zeigt-wirkung. Accessed 23 September 2020

119. MUV SL (2016) Studie zur Reduktion von Mikroverunreinigungen in Gewässern. https://www.evs.de/aktuell/meldungen/archiv/meldung/ artikel/studie-zur-reduktion-von-mikroverunreinigungen-in-gewaessernumweltminister-jost-ueberreicht-rund-222/. Accessed 23 September 2020

120. StMUV BY (2015) Spurenstoffe und vierte Reinigungsstufe für Kläranlagen. https://www.stmuv.bayern.de/themen/wasserwirtschaft/abwasser/spurenstoffe.htm. Accessed 23 September 2020

121. UM BW (2012) Anthropogene Spurenstoffe im Gewässer: Spurenstoffbericht Baden-Württemberg 2012, Stuttgart. https://um.baden-wuerttemberg. de/fileadmin/redaktion/m-um/intern/Dateien/Dokumente/3_Umwelt/ Schutz_natuerlicher_Lebensgrundlagen/Wasser/181120_ArbeitspapierSpurenstoffelimination-kommunale-Klaeranlagen.pdf. Accessed 23 September 2020

122. UM BW (2018) Elimination of micropollutants in municipal wastewater treatment plants in Baden-Württemberg: Working paper [Spurenstoffelimination auf kommunalen Kläranlagen in Baden-Württemberg: Arbeitspapier]. https://um.baden-wuerttemberg.de/fileadmin/redaktion/m-um/intern/ Dateien/Dokumente/3_Umwelt/Schutz_natuerlicher_Lebensgrundlagen/ Wasser/181120_Arbeitspapier-Spurenstoffelimination-kommunale-Klaeranlagen.pdf. Accessed 17 February 2020

\section{Publisher's Note}

Springer Nature remains neutral with regard to jurisdictional claims in published maps and institutional affiliations. 